\title{
Why leave the teaching profession? A longitudinal approach to the prevalence and persistence of teacher turnover intentions
}

\author{
Katariina Räsänen ${ }^{1}$ (D) Janne Pietarinen ${ }^{2} \cdot$ Kirsi Pyhältö $^{3,4} \cdot$ Tiina Soini $^{5}$. \\ Pertti Väisänen ${ }^{2}$
}

Received: 26 August 2019 / Accepted: 19 May 2020 / Published online: 27 May 2020

(c) The Author(s) 2020

\begin{abstract}
Teacher turnover has been recognized as a significant problem in the education worldwide. This study focuses on exploring reasons behind the turnover intentions, and persistence of such intentions in 5-year follow-up among Finnish teachers. Longitudinal survey data were collected from Finnish comprehensive school teachers in 2010 (T1 $n=2310$ ) and 2016 (T2 $n=1450$ ). The results showed that $50 \%$ of the teachers had turnover intentions. Turnover intentions were remarkably persistent, but the reasons for them varied significantly. Lack of professional commitment and factors related to the school system and workload were the main reasons for teacher turnover intention. The results suggest several factors that should be improved simultaneously in the teaching profession to increase teacher job satisfaction and retention.
\end{abstract}

Keywords Teacher turnover - Teacher attrition - Teacher job-dissatisfaction · Teacher career $\cdot$ Teacher retention

Katariina Räsänen

katariina.rasanen@uef.fi

1 School of Applied Educational Science and Teacher Education, University of Eastern Finland, Yliopistonkatu 2, PL 111, 80101 Joensuu, Finland

2 School of Applied Educational Science and Teacher Education, University of Eastern Finland, Joensuu, Finland

3 Faculty of Educational Sciences, University of Oulu, Oulu, Finland

4 Centre for University Teaching and Learning, University of Helsinki, Helsinki, Finland

5 School of Education, University of Tampere, Tampere, Finland 


\section{Introduction}

Teacher career turnover is identified globally as a serious occupational hazard in the field of education (ASTI 2018; OAJ 2018). In many countries, the estimated teacher turnover rate ranges from 13 to $15 \%$ annually (Ingersoll 2001; Nissinen and Välijärvi 2011), and of those who exit the profession, only a third are estimated to return (Sutcher et al. 2016). Even in Finland, where the teaching profession has been traditionally highly appreciated and where teachers have been very committed to their profession, there is a rising concern about teacher jobsatisfaction, the attractiveness of the teaching career, and an increase in turnover (VAKAVA Statistics 2017).

Teacher turnover has severe consequences for the quality of instruction, for students and their learning, and more broadly, for the school community. For instance, there is research evidence proves that teacher turnover negatively affects student engagement and achievement as well as school leadership and the dynamics of the professional community (Guin 2004; Ingersoll 2001; Ronfeldt et al. 2013). A school loses institutional memory due to significant staff changes; changes in staff raise the need for additional resources for recruiting and familiarising new members with the everyday practices adopted by that school community (Borman and Dowling 2008; Ingersoll 2001; MacDonald 1999; Ronfeldt et al. 2013).

Some teachers reflect on possible professional turnover owing to several changes and requirements in the teaching profession (Heikonen et al. 2016; Pyhältö et al. 2011). Teachers perceive that their working conditions are evolving in a negative direction, such as lack of financial resources, or diverse expectations on teaching work. Previous studies have showed that the teaching profession has become considerably more complicated (Hargreaves et al. 2007). Teachers perceive they are working under pressure (Buchanan 2010) and, at the same time, public appreciation for teaching has diminished (Webb et al. 2004). Teachers also perceive that they are simultaneously and continuously facing new developmental tasks in the form of ongoing school reforms and educational innovations. This means less time to perform increased amount of work. Hence, working as a teacher requires more and more the capacity to tolerate continuing change, insecurity, unfinished tasks and personal incompleteness (Husu and Toom 2016).

Teacher turnover intentions have been investigated in several studies (Borman and Dowling 2008; Brill and McCartney 2008; Skaalvik and Skaalvik 2011). A teacher's final decision to leave the teaching profession has typically preceded long-lasting consideration for the reasons, motives, and risks related to and the resources necessary to carry out a significant professional turnover (Clandinin et al. 2009; Heikonen et al. 2016). Moreover, the number of teachers considering a career change seems to increase over time (Ministry of Education and Culture 2007). For instance, recent studies showed that $40-50 \%$ of teachers have reported turnover intentions in Finland (Jokinen et al. 2014; Pyhältö et al. 2015). It is also estimated that 10-15\% of these teachers realised actual turnover behaviour (Nissinen and Välijärvi 2011).

Previous studies have mainly focused on the novice teachers' turnover that is found to be a critical career phase in terms of leaving the teaching profession. 
However, recently, it has also been found that the experienced teachers perceive the increasingly complex working conditions similarly challenging to cope with. For instance, teachers retire earlier than average when compared with other human service professions (Ingersoll and Merill 2012; OECD 2015). However, long-lasting turnover intentions that are not immediate choices made in a particular single event have not been widely studied (DeAngelis et al. 2013). Hence, this study approaches teacher turnover as a pre-phase to the actual teacher attrition process when intentions to leave the teaching profession become more persistent.

Accordingly, this study aims to bridge the gap in the literature on teacher career turnover by longitudinally exploring the sources and persistence of teacher turnover intentions. By analysing the consistency of teacher turnover intentions over time, our study contributes to educational development literature by identifying the prolonged reasons that may push teachers to leave their profession. This provides new insight about the proactive means that can help sustaining teaching profession meaningful and promote teacher retention.

\subsection{Teacher turnover intentions}

Teacher career turnover is commonly used to describe transitions in the teaching profession. Teacher turnover refers either to area transfer within the teaching profession, such as changing the subject(s) to be taught, to migration from one school to another or to leaving the teaching profession (Boe et al. 2007; Ingersoll 2002; Macdonald 1999). We use the term turnover to refer to intentions to leave the teaching profession entirely.

A teacher's turnover intention can be seen as a pre-phase of career turnover (Clandinin et al. 2009; Locke 1968) and one of the strongest predictors of actual career turnover (Griffeth et al. 2000; Locke 1968). The relationship between intention and the implementation of such behaviour has been confirmed by intentionbehaviour studies (e.g. Ajzen et al. 2009). For instance, DeAngelis et al. (2013) have implied that if a novice teacher's intention to quit is prolonged, then it significantly predicts actual turnover behaviour. Whether turnover intention leads to actual turnover or not, it is likely to reflect low-level job satisfaction (Saeed et al. 2014), which has been shown to be related to reduced teacher effectiveness, effort and quality of teaching (Ladd 2011).

\subsection{Factors increasing risk for teacher turnover}

Previous studies suggest that teacher turnover is affected by multiple factors. Both individual attributes, such as personal crisis, stress or frustration (DeAngelis et al. 2013; Skaalvik and Skaalvik 2011), and contextual attributes, such as time constraints, salary or lack of opportunities for personal and professional development, can bring about teacher career turnover (Borman and Dowling 2008; Brill and McCartney 2008; Hughes 2012; Mäkelä and Whipp 2015; Parker 2015; Schaefer et al. 2012). Nevertheless, typically multiple attributes, rather than a single individual or contextual one, contribute to actual turnover behaviour (Clandinin et al. 2014). 
Previous literature has also identified that, emotional exhaustion, burnout, depersonalization, or feelings of low personal accomplishment in the teaching profession increase the risk for teacher turnover (Goddard and Goddard 2006). Additionally, teachers' views of themselves as professionals might influence their decisions. Teacher turnover is closely associated with continuously developing teachers' sense of professional self or identity (Hong 2010). Even if turnover intention leads to staying in the profession, as a protective strategy, a teacher might provide less energy or commitment to teaching to modify or reconfigure her professional identity (Day, Elliot and Kington 2005; Day and Gu 2014).

The factors that activate teacher turnover intention have been found to vary at different career points, in teacher sub-groups and over time (Johnson et al. 2005). In contrast to most earlier studies (Guarino et al. 2006; Ingersoll 2001; Luekens et al. 2004), the latest research has shown that male teachers have higher turnover rates (Passy and Golden 2010) and greater dissatisfaction with the teaching profession (OECD 2015) than their female counterparts. Salary and improving career opportunities by pursuing another career also have a greater impact on the male intention to quit than on the female intention. Health issues or perceived deconstructive changes in teachers' work have a greater impact on female teacher intentions to quit (Luekens et al. 2004). Previous studies have also identified that the highest turnover rates occur among novice teachers (within the first 5 years) (Goldring et al. 2014; Ingersoll and Smith 2003) and the most experienced teachers, whose are approaching retirement age (Guarino et al. 2006).

Novice teachers are usually distracted from teaching either by the work itself (e.g. excessive workload) or by problems that occur in social interaction in the school community (e.g. teacher-student interaction and the professional community) (Lindqvist et al. 2014). The intensification of a teacher's workload is one of the greatest factors that challenge novice teacher's beliefs, attitudes, and understanding of their work (Smethem 2007). Hence, novice teachers' turnover intentions are often related to a perceived mismatch between their perceptions of the teaching profession and their experienced reality of the everyday work that may become an emotional burden to them (Hong 2010). In turn, research findings suggest that a positive collegial climate and social support seem to be essential for keeping novice teachers in the teaching profession (Pogodzinski et al. 2013; Pomaki et al. 2010).

Above all, administrative support, such as giving teachers more desired responsibilities and providing opportunities for professional development and time for collaboration and planning, is most consistently associated with teacher decisions to remain in or leave the profession (Ingersoll and Kralik 2004; Ladd 2011; Leung and Lee 2006). Teachers who find their administrators to be unsupportive are more than twice as likely to leave as those who feel supported by educational administration (Sutcher et al. 2016).

In turn, the decision to leave the profession in late career typically has personal reasons: the desire to spend more time with family or the intention to retire earlier than expected (Borman and Dowling 2008). Yet, it is estimated that only about $12 \%$ of teacher turnover results from early retirement (Ingersoll 2001). Financial factors, feelings of emotional exhaustion and dissatisfaction with nonteaching-related workload (such as meetings and paperwork) have an important influence on teachers' 
retirement decision (Van Droogenbroeck and Spruyt 2014). Experienced teachers describe that the nature of their work has changed as expected and the workload has increased (Buchanan et al. 2013). Moreover, health issues and aging have a greater effect on experienced teachers' decision to leave the teaching profession earlier than planned (Day and Gu 2009). However, the nature of the teachers' work includes change as a natural and permanent state, so it is understandable that current work no longer resembles what it was in the beginning of a teacher's career. The educational reforms in schools are simultaneously often experienced as challenging and may lead to increased teacher stress, risk for burnout, and career turnover (Little and Bartlett 2002).

According to Ashforth (2001), career change situations are also associated with the pressure from work (e.g. job dissatisfaction) or weak professional prospects that make other options attractive (e.g. rival and interesting offers from other sectors). Accordingly, teacher turnover intentions can be affected positively or negatively by regulating several internal and/or external factors. Individual teachers have different expectations and priorities for their work and their working environment. Therefore, it is impossible to specify a simple set of factors that contribute retaining teachers. Accordingly, the sources of teacher turnover intention, the gradually proceeding decision-making in terms of chancing teaching profession, and further, the multiple ways of supporting teachers' retention and job-satisfaction should be more in-depth understood (Heikonen et al. 2016; Johnson et al. 2005; Soini et al. 2010).

\subsection{Aims}

This study aims to gain a better understanding of teacher career turnover by exploring the sources and persistence of teacher turnover intentions. Prolonged reasons that may push a teacher to leave their profession and the consistency of teacher turnover intentions over time are explored. The following research questions were addressed:

(1) To what extent do teachers have career turnover intentions; what factors push teachers to consider career change; and how persistent are identified turnover intentions and the factors that activated them over time?

(2) Are the factors and actual turnover intentions related to teacher gender, different teacher groups (i.e. primary, subject or special education teacher) or career phase?

\section{Method}

\subsection{Research context}

Nearly all (95\%) Finnish teachers are fully qualified (Kumpulainen 2017). The high level of training is seen as necessary as teachers in Finland are very autonomous 
professionally. Primary school teachers complete a 5-year university Master of Arts in Education degree after which they receive a formal qualification to teach grades 1-6. Subject teachers who typically teach grades 7-9 (lower secondary school) usually have a Master's degree in a subject domain with an additional compulsory 1 year of study (60 credit points) in educational science. Special education teachers who teach in both grades 1-9 have a Master's degree in special education. Principals in Finland are required to be qualified to teach at the level of the school they lead, and they must complete a university programme in Educational Leadership (see Finnish National Agency for Education).

Finland has no private school system; comprehensive schooling is publicly funded. Comprehensive school (grades 1-9) offers a similar basic education to all children. No separation of students into academic or vocational studies is made during these years. This means that only a few opportunities for career advancement in teaching exists in Finland because educational institutions do not have hierarchies based on pay or other forms of appreciation. A teacher may extend their teaching qualifications and apply for a teaching position at a higher level of education; a primary school teacher, for example, can become a qualified subject teacher. Some teachers progress to headmaster positions during their careers, and some move on to other educational professions. (OECD 2003; Toom and Husu 2016).

The average age of Finnish teachers is high: $39 \%$ are over 50 years old, which increases the number of retirements in the near future (Kumpulainen 2017). Accordingly, the age structure for teachers in Finland is similar than in many European countries (OECD 2012).

\subsection{Participants}

This study used data collected from Finnish comprehensive school teachers in a national longitudinal survey that utilised probability sampling $(N=6000)$. The longitudinal research design included a 5-year follow-up with two measurement points. Research ethical principles were taken into account in the data gathering phase. Participation in the study was voluntary, which was made clear for the respondents in the survey, and the collected data was anonymised before analysing and storing it.

Time 1 The first data collection (measurement T1) was conducted in 2010. Altogether, 2310 comprehensive school teachers, including primary $(n=815 ; 35 \%)$, subject $(n=729 ; 32 \%)$, and special education teachers $(n=761 ; 33 \%)$ completed the survey at (T1). The total response rate was $39 \%$. The mean age of the respondents was 45.3 years $(\mathrm{SD}=9.84$; Min/Max: 25/68 years). The majority of the respondents were female $(n=1878 ; 81 \%)$ and the minority were male $(n=429$; $19 \%)$. All respondents had MA degrees, and they were in various phases of their careers. Hence, the response rates for the different teacher groups (primary, subject, and special education teachers) were also acceptable. The schools in which the participants worked varied in terms of size and grades taught.

Time 2 The second data collection (measurement T2) in 2016 involved 1504 teachers, including primary $(n=526 ; 36 \%)$, subject $(n=465 ; 32 \%)$, and special 
Table 1 The non-response analysis

\begin{tabular}{|c|c|c|c|c|}
\hline \multirow[t]{2}{*}{$\mathrm{N}$} & \multicolumn{2}{|l|}{$2307 / 2310$} & \multicolumn{2}{|l|}{$1473 / 1450$} \\
\hline & Sample T1 & Population 2010 & Sample T2 & Population 2016 \\
\hline \multicolumn{5}{|l|}{ Gender } \\
\hline Female & 1878 & 1684 & 1219 & 1134 \\
\hline Male & 429 & 623 & 254 & 339 \\
\hline \multicolumn{5}{|l|}{ Age } \\
\hline$<40$ & 878 & 738 & 276 & 412 \\
\hline 40-49 years & 693 & 761 & 508 & 486 \\
\hline$\geq 50$ years & 739 & 807 & 667 & 574 \\
\hline
\end{tabular}

education teachers $(n=486 ; 33 \%)$. Accordingly, the response rate of the followup research design was $65 \%$. The mean age of the respondents was 48.8 years ( $\mathrm{SD}=9.40$; Min/Max: 30/69 years). The majority of the respondents (83\%) were female teachers $(n=1219)$, and the minority were male teachers $(n=254 ; 17 \%)$.

The non-response analysis, i.e. comparing the sample with teacher population statistics in Finland, showed that the sample representation was moderately plausible (see Table 1). (See also the National Board of Education 2010, 2017.)

\subsection{Measurements and data analysis}

Teacher turnover intentions were measured with one item: "Have you considered to leave the profession?" (yes/no). The one item measure has been used and validated in prior studies as a reliable measure of teacher turnover intention (e.g. Goddard and Goddard 2006). Any respondent who stated that intention to leave was classified as a potential leaver. Respondents who had reported turnover intentions were asked to further clarify why they had considered changing their profession (Actual question: "Why").

Teachers' open-ended responses to this question were qualitatively content analysed (see also Bauer and Gaskell 2000; Berelson 1952). T1 and T2 responses were separately analysed utilising the same analysis protocol. The content analysis consisted of complementary phases.

At first all the text segments in which a teacher reported a reason for their career turnover intentions were coded into the same category. The five categories were:

- Multiple factors

Several (more than one) broad-based and equally important school system, school level, and/or individual level factors perceived by a teacher that cover different combinations of the following single-factor categories 
- The school system

The reasons for which a teacher perceives that she/he cannot influence in her/his work in terms of resources, employment contracts, salary and teacher job description or work performance

- Challenges of interaction

The perceived challenges of social interaction with school staff, students, parents or educational stakeholders in the teacher's work

- Workload

Teachers' affective and/or physical responses to perceived heavy workload

- Lack of commitment

Perceived alienation from the professional goals, values and personal investments that guided the career choice, committed to the teaching profession and strived for using the best effort in the school's everyday work.

Both measurement timepoints were used for mapping intentions to leave and to observe the prevalence (frequencies) and the persistence of the career turnover intention. The analysis resulted in 2283 responses at T1, 1470 responses at T2, and 1427 responses from both measurement times. The aim of this study was to identify the prolonged reasons that may push a teacher to leave their profession, and for this reason, solely follow-up data was used. Hence, the teachers who only responded at T1 $856(37.5 \%)$ or only at T2 $43(2.9 \%)$ were not included in the final analysis.

The focused data group of teachers with persistent turnover intentions was formed from those respondents that, at both the measurement times, reported turnover intentions and responded to the open-ended question. This group $(n=313$ teachers $)$ was given closer examination in order to explore the persistence of turnover intentions and the factors that push teachers to consider leaving.

Finally, different reasons for turnover intentions and teacher background variables were cross-tabulated with the intention of determining if those reasons were related to gender (female/male), teacher group (primary, subject, and special education teacher), and/or work experience in the teaching profession (novice teachers 0-5 years, mid-career teachers 6-20 years, the most experienced teachers $>21$ years).

\section{Results}

\subsection{The prevalence and persistence of teacher career turnover intentions}

The results showed that teacher intentions to leave the teaching profession were quite common. Half of the teachers $(49.5 \%, \mathrm{n}=707)$ had turnover intentions either momentarily $(25.5 \%, \mathrm{n}=363)$ or persistently $(24.1 \%, \mathrm{n}=344)$. The other half 
Table 2 Turnover intentions at $\mathrm{T} 1$ and $\mathrm{T} 2 \%$

\begin{tabular}{lll}
\hline & $\mathrm{T} 1$ & $\mathrm{~T} 2$ \\
\hline $\mathrm{N}$ & 2283 & 1470 \\
Female & $37(\mathrm{n} \mathrm{686)}$ & $33.8(\mathrm{n} \mathrm{412})$ \\
Male & $45.7(\mathrm{n} \mathrm{193)}$ & $34.6(\mathrm{n} \mathrm{88})$ \\
Total & $38.6(\mathrm{n} \mathrm{881)}$ & $35(\mathrm{n} \mathrm{508)}$ \\
\hline
\end{tabular}

$(50.5 \%, \mathrm{n}=720)$ reported that they had not considered a career change at either measurement time. In terms of the prevalence of turnover intentions, male teachers considered career change more frequently than their female counterparts. The difference between genders was also statistically significant $\left(\chi^{2}(2)=11.798, p=0.003\right)$. A comparison between teacher groups did not show any statistically significant difference. However, those who had 6-20 years working experience most frequently reported turnover intentions $(46.3 \%, n=534)$. A third of those who had been working 5 years or less $(34.5 \%, n=98)$ and less than a third $(29.3 \%, n=244)$ of the experienced teachers ( 21 or more years of working experience) had considered a career change.

The persistency of teacher turnover intentions was also significant. Table 2 shows that, at the both measurement times, a significant number of the teachers had reported career turnover intentions. Male teacher turnover intentions dropped noticeably during the 5-year follow-up period while female teacher turnover intentions fell more moderately (see Table 2). Perceived turnover intentions were similar across the primary, subject and special education teacher groups. Results indicate that turnover intentions remained consistent over time; $62 \%(n=344)$ of those teachers who had initially reported turnover intentions still considered leaving the profession 5 years later.

\subsection{The reasons for teacher turnover intention}

Further investigation showed that teachers' $\left(n=313^{1}\right)$ reasons for considering a career turnover remained consistent at the 5-year follow-up (see Fig. 1). Teachers were typically able to identify the major reason for their profound consideration of a career change.

The five reasons identified were attributed to system-wide, school- and personallevels that launched and sustained teacher turnover intentions: multiple factors, the school system, challenges of interaction, workload and the lack of commitment. However, the minor changes in the perceived significance and emphasis of the reasons were detected over time. At the both time points, teachers emphasized the lack of commitment, high workload and disappointment towards the school system as the main reasons for their turnover intentions.

\footnotetext{
1313 out of 344 teachers that have considered a career change also described the reason for their turnover intentions.
} 


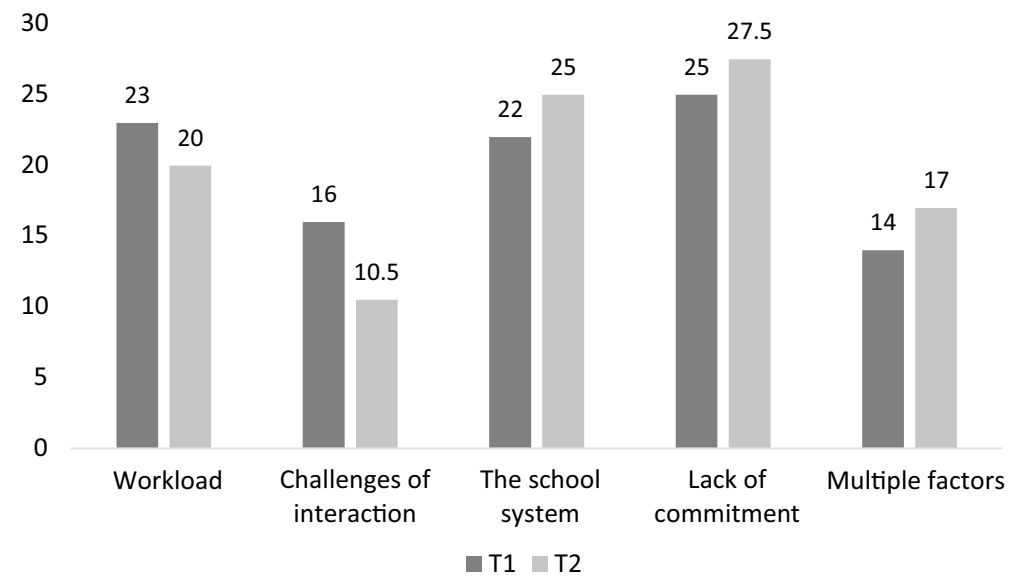

Fig. 1 Categorized factors behind the career turnover intention at T1 and T2\%

\subsubsection{Multiple factors}

Teachers perceived that their turnover intention was affected by several equally important factors that pertained not only to the teaching profession but also to leisure time with family. More specifically, $14.1 \%(n=64)$ of teachers at $(\mathrm{T} 1)$ and $16.9 \%$ $(n=53)$ of teachers at T2 experienced that severe disadvantages of their work triggered their turnover intention. The combination of the following factors that pushed teachers to leave the profession was especially emphasised: an experienced workload and lack of commitment at the personal level, perceived challenges in social interaction and environment at the school level, and perceived disappointment with societal and educational changes in the school system that faced the teachers.

For several cumulative reasons, the perceived prolonged burdening and alienation from the teaching profession increased, and hence, leaving the teaching profession was seen as a functional means to solve professional disharmony.

The work is mentally hard, the work community has not been encouraging, the management is unfair to the teachers and does not treat everyone equally, the parents are always insisting that you do more, there is a lot of work on top of the teaching, there is no help from outside the school with pupils who are really difficult (the queues are too long everywhere), not enough resources, low wages, almost zero benefits... (T1) Too much stress, the expectations (the parents, the digital leap, the new curriculum, etc.), the pressure, the work tasks that have to be done at home (difficult when you have small children), criticism in the media, the busyness, the so-called "paperwork" due to Wilma, the pay is too low compared to the workload, some of my same-age colleagues have already made a career change and they are very happy now.

(Female mid-career special education teacher, 5512, T2).

\footnotetext{
${ }^{2}$ Wilma is the web interface for the student administration program.
} 


\subsubsection{School system}

The perceived disappointment with the societal and educational changes in the school system faced by teachers was also a significant reason for teacher turnover intentions (T1 21.7\%, $n=68$; T2 24.6\%, $n=77$ ). More specifically, the increased work requirements in addition to teaching student in a classroom setting such as administrative work or supporting the students' families, the perceived low appreciation and low salary level in the teaching profession launched the consideration of making a career change. Moreover, teachers perceived that educational changes were planned and determined as a top-down decision-making process rather than knowing and taking into account teachers' everyday working reality (i.e. a bottomup process).

How difficult the work is, not the teaching or the work itself, but mainly how the changes/requirements come from parties who do not have enough knowledge of the practical side of the work/everyday problems. (Female mid-career special education teacher, 5865, T1).

Teachers also reported that the lower financial resources allocated to education have produced several concrete changes in their work, and these factors have pushed them to consider leaving the teaching profession. For instance, uncertainty related to the continuity of teacher vacancies in merged school districts, increased class sizes and unbiased ratio between students with special needs and teachers to support those students were identified as the main reasons for teacher turnover intentions in everyday work.

The pupil material and the resources do not meet. Costs are being cut constantly, and the pupils need smaller class sizes and more remedial education. Employment is temporary, and it is really difficult to get a permanent post. (Female mid career classroom teacher, 897, T1).

\subsubsection{Challenges of interaction}

The perceived social problems with educational stakeholders, colleagues in the professional community, students and/or parents were also significant reasons for career turnover intentions (T1 16.3\%, $n=51 ; \mathrm{T} 210.5 \%, n=33$ ). Teachers perceived that their work required advanced human relations skills. Teachers also emphasized the importance of professional support, received trust and autonomy from all levels and parties that influence their work, such as educational stakeholders, principals, colleagues, students and parents.

Teachers perceived the lack of sufficient professional support, received trust and autonomy launched turnover intentions over time. The social reasons that seemed to alienate teachers from their professional work were intertwined with the teachers' views of principals' capacity to orchestrate participatory and encouraging working conditions for all in the school community. 
Getting a new headmaster to our school brought a lot of inequality and more work tasks, and the flow of information "stopped". (Female mid career special education teacher, 5971, T2).

The headmaster runs a dictatorship, and nobody helps even if the whole teaching staff needs help! (Female mid career subject teacher, 946, T1).

Parent-teacher interaction contributed to a career change intention. Disadvantaged families who needed additional support, demanding parents with high expectations on the school and who questioned the teacher's professional skills, even in a hostile way, contributed to the intention.

Teacher's work requires interpersonal skills; even though I like working as a teacher, it is very exhausting mentally. (Male experienced primary school teacher, 1910, T2).

Challenging guardians who are difficult to deal with cause stress sometimes. Guardians question the teacher's professional skills, which sucks the energy needed to do the actual teaching work. Luckily, in our municipality and school, we have a good multi-professional network. (Female experienced primary school teacher, 739, T2).

Student-teacher interaction was also perceived as a contributing factor. Various problems in terms of the students' lasting negative attitudes towards the school and destructive behaviour has occurred. Moreover, the experienced increase in the heterogeneity of the students' capacity to focus on learning and resources to cope with the multiple tasks provided by the school seemed to launch the teacher turnover intentions.

Schoolwork has become very short-sighted. Most pupils have a very poor attention span; the difference between pupils is huge. (Female mid-career primary school teacher, 1499, T1).

\subsubsection{Workload}

A heavier workload that expressed itself as mental and/or physical symptoms (T1 $23.3 \% n=72$; T2 $20.6 \% n=64$ ) also contributed to teacher intentions to leave the profession. These factors included work-related stress, emotional exhaustion, and a sense of inadequacy. Teachers' professional commitment to support all students in learning combined with the perceived challenge of setting their own limits resulted in unbalanced working conditions for some teachers. The work-related burden was perceived as varying with the period of the school semester. The unbalanced distribution of work between teachers was also perceived as a source of burden and as an additional factor that contributed to teacher turnover intentions.

I don't know how to set boundaries between working and not working. I do too much and I wear myself out. In this work, you are never done (learning). (Female mid-career primary school teacher, 1015, T1). 
My stress levels go through the roof when there are parties and celebrations coming up. I am one of the more conscientious teachers, and often at the end of the semester, there are exams and performances, and I stress myself out to the brink of self-destruction. Other people's casual attitude (their classes do not perform) really makes me furious. Because I am so conscientious, I am often given a challenging class and getting the pupils of a challenging class to perform causes horrible - awful - unbelievable stress. (The most experienced primary school teacher, female, 587, T2).

Large-scale educational reforms and the ensuing rapid changes and expectations related to the teaching profession have been experienced as a burden. Especially experienced teachers worried about their capacity to develop new pedagogical practices and cope with new demands set by the educational system with the limited resources available. They were also worried about aging and personal resources for coping with future challenges of the profession until retirement age.

The job description of teachers has changed and is changing, but I feel that I am not given enough tools and opportunities to do my work. The constant feeling of inadequacy is tiring and confusing. What irritates me is how the executives present idealistic ideas but do not give the resources needed to put them into practice. (Female mid-career subject teacher, 3329, T1).

Ageing is starting to be a big problem in my work, both physically and mentally. (The most experienced subject teacher, female, 3015, T2).

The work is mentally straining, I am growing old before my time. (Midcareer subject teacher, male, 3694, T1).

\subsubsection{Lack of commitment}

The lack of professional variation within the profession and few opportunities to learn and establish something new that have personal relevance and meaning for the future teaching work were perceived most significantly as a reason for turnover intention and strengthened over time (T1 24.9\%, $n=78$; T2 27.5\%, $n=86$ ).

I am not motivated or excited about my work enough to do it and be happy - or even feel satisfied with my work and life as a whole - all the way up to retirement age. (Female novice primary school teacher, 970, T2).

Sometimes I feel like I have been doing this for so long that it would be nice to try something else. Many of my friends have advanced in their career - "I AM STUCK WHERE I AM". (Female mid-career special education teacher, 5846, T1).

Everyday life is killing me slowly, no career advancement opportunities except becoming a headmaster, and that is the last job that I want. (Male mid-career primary school teacher, 447, T2).

These experiences had also impact on the teachers' perceived professional identity: the optimism and hope adopted by teachers were gradually replaced with 
pessimism and cynical attitudes towards the profession and this, in turn, resulted in frustration between future career aspirations and everyday realities of the profession. As a result, a lack of commitment launched consideration of a new career, studies or retirement.

\subsection{The persistence of the reasons given for turnover intentions}

The results reveal a novel finding: Although turnover intentions were considerably persistent over time, the reasons behind consideration of making a career change were not. The reasons for turnover intentions changed remarkably, and only $40 \%$ of teachers reported the same factor at both measurement times. ${ }^{3}$ Persistence of such reasons was the greatest in the lack of commitment category, in which $15 \%(n=47)$ of teachers perceived as the main reason for considering the career change at the both measurement times.

The results show that teachers perceived a lack of commitment as the main reason for turnover intentions at T1. Moreover, a lack of commitment was the most common reason for turnover intentions among those teachers who did not respond to the survey at T2. ${ }^{4}$ This may indicate that personal-level reasons, such as lack of commitment, transform teacher turnover intentions into concrete career change behaviour. A comparison between the teacher groups revealed no statistically significant differences although persistent turnover intentions were the highest among subject teachers $(37 \% ; n=115)$, almost as high among primary school teachers $(34 \% ; n=106)$ and the lowest among special education teachers $(29 \% ; n=92)$.

\subsection{A comparison of the reasons for turnover intention between teacher categories}

Further investigation showed that there were statistically significant gendered differences in teachers' reasons for turnover intentions at the first measurement point (T1) $\left(\mathrm{x}^{2}(4)=17.537, \mathrm{p}=0.002\right.$, Cramer's $\left.\mathrm{V}=0.24\right)$. Male teachers reported a lack of commitment as the main reason for turnover intentions more often $39.3 \%$; $n=22)$ than their female counterparts $(21.9 \% ; n=56)$. Female teachers, in contrast, perceived more challenges in social interaction of the teaching profession $(18.4 \%$; $n=47)$ than male teachers $(7.1 \% ; n=4)$, and the experienced workload was more often a reason for female teacher turnover intentions $(26 \% ; n=67)$ than for male teachers $(9 \% ; n=5)$.

Five years later at T2, male teachers still reported more often $(37.5 \% ; n=21)$ the lack of commitment as a significant reason to consider a career change than female teachers $(25 \% ; n=64)$. Statistics show that the observed gender difference was slightly less at this measurement point $\left(x^{2}(4)=10.476, p=0.033\right.$, Cramer's

\footnotetext{
3 The Kappa value $(0.24 ; p<0.001)$ less than 0.4 indicates that the reasons for turnover intentions compared between the T1 and T2 measure points were not persistent (Breakwell et al. 2000).

4 The proportion of non-respondents to T2 in each category at T1 (between the T1 and T2 measurement points): multiple factors $(13.3 \%)$, the school system $(22.1 \%)$, challenges of interaction (13\%), workload (18.8\%), and lack of commitment (32.8\%).
} 
$\mathrm{V}=0.18$ ). There were no statistically significant differences in reasons for considering a career change between the other teacher categories.

\section{Discussion}

This study explored the prevalence and persistence of teacher turnover intentions and reasons that trigger a serious career change consideration. The results showed that teacher turnover intentions were surprisingly prevalent. In $2010,39 \%$ out of 2310 teachers and, in 2016, 35\% out of 1450 teachers reported turnover intentions. These findings are consistent with earlier studies worldwide (40\%; Ladd 2011), but these turnover ratios are noticeably higher than previous statistics in Finland (average 23-25\%; OECD 2015). Teachers' increased consideration of a career change is also surprising from the perspective of recent studies related to teacher job satisfaction (e.g. OECD 2015). Even though a majority of teachers responded that the positive sides of their work still dominated, the increase in turnover intentions may indicate a gradually developing disharmony between perceived work demands and insufficient resources in the teaching profession.

Recent studies have also shown that perceived teacher autonomy (Lundström 2015) and sustaining the core meaning of the teaching profession have become more complicated (Lindén 2010). Teachers with prolonged turnover intentions seem to relate considering a career change with system-wide challenges, such as a topdown decision-making process, which additionally regulate and challenge teachers' perceived autonomy in their everyday work. For instance, during this longitudinal study, several significant educational reforms were initiated, such as enacting an inclusion policy in schools and renewing the national core curriculum. These ongoing educational reforms are intended to further develop a relatively well-performing educational system (OECD 2019a, b) but require new professional training and seem to increase the pressure on teachers to perform even better at the individual and school community levels, which, in turn, may trigger turnover intentions among professionals in the field.

The results also show that teacher turnover intentions have remained consistent over time. The majority of the teachers who initially reported turnover intentions considered leaving the teaching profession also 5 years later. However, the identified reasons for the persistent consideration of making a career change varied statistically significantly over time. The main reasons were multiple factors, the school system, challenges of interaction, workload and lack of commitment. This novel finding indicates that teachers' prolonged turnover intention is a continuous teacher-driven negotiation process. In this process, the perceived fit between the teacher and their working environment is permanently and profoundly biased. Hence, the perceived disengagement and alienation from the profession may have different justifications over time. This finding means that whether or not a prolonged turnover intention leads to actual turnover, it is likely to reflect low job satisfaction (Saeed et al. 2014) and reduced teacher performance (Ladd 2011). Future challenges are to create contexts in which teachers can make meaningful connections between the priorities of 
the school and their personal, professional and collective identity and commitment (Day et al. 2005).

The results in this study do not support previous findings about the higher turnover rates or turnover intentions of novice teachers (Goldring et al. 2014; Elferset al. 2017). Instead, mid-career teachers reported more turnover intentions than novices or the most experienced teachers. This finding points out the system-wide need for developing multiple opportunities for professional learning throughout the entire teaching career. Mid-career teachers may experience an impasse, having a lot of expertise and responsibility but no opportunities to advance in their career (Day and $\mathrm{Gu}$ 2007). It can be speculated that mid-career teachers lack support to thrive and develop professionally. Turnover intentions in this teacher category are especially harmful for the professional community. Teachers at the high point of their career are a valuable resource for mentoring early career teachers; they have cumulative knowledge and skills necessary to make changes and involve themselves in the school's pedagogical development (e.g. Elfers et al. 2017).

It was also found that male teachers repeatedly reported more turnover intentions than female teachers. The lower number of intentions to quit within 5 years was mainly due to the lower proportion of male respondents at $\mathrm{T} 2$ than female (i.e. non-response ratio in T2: male teachers $18.7 \%$ vs. female teachers $13.3 \%$ ). This, in turn, might indicate that male teachers make bolder career changes (see also Luekens et al. 2004). The results indicate that especially male teachers consider a lack of commitment to the teaching profession as the main cause for turnover intention. The working life experiences of female and male teachers appear to differ, and this difference should be considered in terms of teacher retention. Lack of commitment was also the most persistent reason for considering a career change. This may reflect the ongoing process in which the teaching profession is changing so that the profession no longer offers a clear object of attachment (Lindén 2010). It may also reveal an unsuccessful career choice or lack of alternative career choices. Hence, personal suitability and commitment to the teaching profession should be profoundly evaluated in the process of student selection for teacher education (e.g. Kari 2002).

Lack of commitment as a source of teacher turnover is alarming not only because it may lead to actual turnover. Teacher professional commitment is positively related to teacher efficacy (Chan et al. 2008) and predicts organisational citizenship behaviour toward students, for example participatory decision-making. (Somech and Bogler 2002). Moreover, teachers who are highly committed to their profession tend to invest extra efforts to stimulate students' learning (Day and Gu 2007, 2009).

Teachers also reported that a heavy workload was one of the main reasons for considering a career change. However, workload was not as dominant a factor in turnover intentions in the present study as in previous ones (Smithers and Robinson 2003; Skaalvik and Skaalvik 2011). Nevertheless, a perceived high workload is a crucial stress factor that drains emotional resources and makes it harder to continue in the profession until retirement (Droogenbroeck and Spruyt 2016). The perceived problems in social interaction were also a source of career change consideration. In the school's social environment, teachers perceived leadership practice as one of the most significant pulling or pushing determinants of turnover intentions. Instances included perceived unequal treatment and top-down leadership practices. Teachers 
face challenges in terms of sustaining constructive interaction with colleagues, students, and parents. Teachers perceived that struggling with the multiple tasks of meeting all the academic and emotional needs of individual learners (Coates 2015) and providing sufficient support, especially to children with special needs, were significant sources of feelings of inadequacy.

Results suggest that the meaning of social relations in teaching is higher for female than for male teachers, which has been found in previous research (Zou 2015). The results are also in line with previous findings that female employees report both overall higher workloads and levels of emotional exhaustion than male employees (Maslach et al. 1996; Lau et al. 2005; Droogenbroeck et al. 2016).

System-wide factors, such as disappointment in the school system, were the third biggest category triggering turnover intentions. Teachers perceived that the lack of opportunities to influence their work (e.g. large class sizes combined with heterogenous student groups), an expansive job description, and low salary contributed increased discrepancy between the perceived work demands and insufficient resources in the teaching profession, and caused them to consider other career choices (e.g. Droogenbroeck and Spruyt 2014; Johnson et al. 2005). This is a significant finding in the sense that teachers in Finland are regarded as highly autonomous experts with substantial influence on their work and are broadly appreciated in society (Pollari et al. 2018). The criticism of the school system and restrictions on autonomy of the work may reflect critical orientation and ownership in terms of the teaching profession. However, this criticism may also reflect the change in working conditions experienced by professionals in the educational system in recent years. This criticism could also be a sign of teachers' dissatisfaction with the simultaneous educational reforms and the lack of resources to commit to and fulfil those reforms or dissatisfaction with the increased bureaucracy in the school communities (Coates 2015; Southern 2018).

\section{Limitations of the study}

The longitudinal data were collected from 2310 comprehensive school teachers around Finland. Because of the distinctive features of the Finnish educational system (e.g. emphasis on teacher autonomy), one must be cautious in generalising the results to school contexts in other countries. Moreover, even though the sample size was notable, it was not completely representative of Finnish school teachers. More specifically, female teachers (T1: Chi-square 46.342; $p<0.001$ and T2: Chi-square $15.254 ; p<0.001)$ and teachers less than 40 years of age (T1: Chi-square 18.133; $p<0.001$ and T2: Chi-square 34.191; $p<0.001)$ were over-represented in the samples at both measurement times, and hence, a generalisation of the results should be considered with caution. However, due to the large sample size and the rich quantified data, the findings are transferable to other studies aimed at understanding the dynamics of teacher turnover intentions and the gradually developing process of teacher attrition.

The longitudinal data analysis was cross checked by two of the authors to optimise the power of the [researcher] triangulation, and to further increase the 
confirmability and transferability of the results (e.g. Bauer and Gaskell 2000). In practice, the consistent criteria and clear distinction between the categories related to career turnover intentions were proactively developed in the data-driven process. Finally, the aim of the study was to understand the sources and persistence of teacher turnover intentions and, hence, actual behaviour in terms of leaving the teaching profession was not possible to identify. Accordingly, a combination of teacher intentions and actual behaviour would be needed for future longitudinal teacher attrition research designs.

\section{Conclusion}

The results showed that half of the teachers had turnover intentions. Turnover intentions were remarkably consistent over time, but the reasons for them varied significantly. Even though teachers typically gave one major reason for considering a career change, presumably several factors exist behind the actual turnover (Clandinin et al. 2014; Johnson et al. 2005). Findings here indicate that the factors that have launched prolonged turnover intentions reflect the biased fit between the teacher and their working environment. This has, in turn, translated over time into a dysfunctional coping strategy, especially for exhausted and/or alienated teachers in their everyday work.

Consequently, to prevent teacher turnover intentions at school and individual levels, the teacher-working environment fit needs active monitoring and developing in the professional community. In turn, at the system-wide and societal levels, appreciation of the teaching profession is not purely sustained by developing societal structures, such as compatible payment. Balancing the top-down-bottom-up dialog is also needed to promote meaningful and ambitious enough professional learning for autonomous teachers and contribute to the further development of the educational system.

Acknowledgements Open access funding provided by University of Eastern Finland (UEF) including Kuopio University Hospital. This work was supported by the Ministry of Education and Culture under Grant (6600567); the Academy of Finland under Grant Number (295022) and the Doctoral Programme in Educational Studies, Philosophical Faculty, University of Eastern Finland.

\section{Compliance with ethical standards}

Conflict of interest There is no potential conflict of interest.

Open Access This article is licensed under a Creative Commons Attribution 4.0 International License, which permits use, sharing, adaptation, distribution and reproduction in any medium or format, as long as you give appropriate credit to the original author(s) and the source, provide a link to the Creative Commons licence, and indicate if changes were made. The images or other third party material in this article are included in the article's Creative Commons licence, unless indicated otherwise in a credit line to the material. If material is not included in the article's Creative Commons licence and your intended use is not permitted by statutory regulation or exceeds the permitted use, you will need to obtain permission directly from the copyright holder. To view a copy of this licence, visit http://creativecommons.org/licen ses/by/4.0/. 


\section{References}

Ajzen, I., Czasch, C., \& Flood, M. G. (2009). From intentions to behavior: Implementation intention, commitment, and conscientiousness. Journal of Applied Social Psychology, 39, 1356-1372. https:// doi.org/10.1111/j.1559-1816.2009.00485.x.

Ashforth, B. (2001). Role transitions in organizational life: An identity-based perspective. New York: Lawrence Erlbaum Associates.

ASTI (Association of Secondary Teachers, Ireland)/RED C. (2018). Teachers'work: Work demands and work intensity, March 2018. Retrieved 23 March 2018 from https://www.asti.ie/uploads/media/ ASTI_-_Survey_of_teachers_-_March_2018.pdf.

Bauer, M., \& Gaskell, G. (Eds.). (2000). Qualitative researching with text, image and sound. A practical handbook. London: Sage.

Berelson, B. (1952). Content analysis in communication research. New York: The Free Press.

Boe, E., Cook, L., \& Sunderland, R. (2007). Trends in the turnover of teachers from 1991 to 2004: Attrition, teaching area transfer, and school migration. Philadelphia, PA: University of Pennsylvania.

Borman, G., \& Dowling, N. (2008). Teacher attrition and retention: A meta-analytic and narrative review of the research. Review of Educational Research, 78(3), 367-409.

Breakwell, G. M., Hammond, S., \& Fife-Schaw, C. (Eds.). (2000). Research methods in psychology. London: Sage Publications.

Brill, S., \& McCartney, A. (2008). Stopping the revolving door: Increasing teacher retention. Politics \& Policy, 36(5), 750-774. https://doi.org/10.1111/j.1747-1346.2008.00133.x.

Buchanan, J. (2010). May I be excused? Why teachers leave the profession. Asia Pacific Journal of Education, 30(2), 199-211. https://doi.org/10.1080/02188791003721952.

Buchanan, J., Prescott, A., Schuck, S., Aubusson, P., \& Burke, P. (2013). Teacher retention and attrition: Views of early career teachers. Australian Journal of Teacher Education, 38(3), 112-129. https:// doi.org/10.14221/ajte.2013v38n3.9.

Chan, W.-Y., Lau, S., Nie, Y., Lim, S., \& Hogan, D. (2008). Organizational and personal predictors of teacher commitment: The mediating role of teacher efficacy and identification with school. American Educational Research Journal, 35, 597-630. https://doi.org/10.3102/0002831208318259.

Clandinin, D. J., Downey, C. A., \& Huber, J. (2009). Attending to changing landscapes: Shaping the interwoven identities of teachers and teacher educators. Asia-Pacific Journal of Teacher Education, 37, 141-154. https://doi.org/10.1080/13598660902806316.

Clandinin, D. J., Long, J., Schaefer, L., Downey, C. A., Steeves, P., Pinnegar, E., et al. (2014). Early career teacher attrition: Intentions of teachers beginning. Teaching Education, 26(1), 1-16. https:// doi.org/10.1080/10476210.2014.996746.

Coates, M. (2015). Principals' perceived influence over new teacher retention. Doctoral Dissertation 2/288. Retrieved from https://scholarworks.umass.edu/dissertations_2/288.

Day, C., Elliot, B., \& Kington, A. (2005). Reform, standards and teacher identity: Challenges of sustaining commitment. Teaching and Teacher Education, 21(5), 563-577.

Day, C., \& Gu, Q. (2007). Variations in the conditions for teachers' professional learning and development: Sustaining commitment and effectiveness over a career. Oxford Review of Education, 33(4), 423-443. https://doi.org/10.1080/03054980701450746.

Day, C., \& Gu, Q. (2009). Veteran teachers: Commitment, resilience and quality retention. Teachers and Teaching: Theory and Practice, 15(4), 441-457. https://doi.org/10.1080/13540600903057211.

Day, C., \& Gu, Q. (2014). Resilient teachers, resilient schools. Building and sustaining quality in testing times. London: Routledge. https://doi.org/10.4324/9780203578490.

DeAngelis, K., Wall, A., \& Che, J. (2013). The impact of preservice preparation and early career support on novice teacher's career intentions and decisions. Journal of Teacher Education, 64(4), 338-355. https://doi.org/10.1177/0022487113488945.

Droogenbroeck, F., \& Spruyt, B. (2016). I ain’t gonna make it. Comparing job demands-resources and attrition intention between senior teachers and senior employees of six other occupational categories in Flanders. The International Journal of Aging and Human Development, 83(2), 128-155. https:// doi.org/10.1177/0091415016647729.

Elfers, A., Plecki, M., \& Van Windekens, A. (2017). Understanding teacher retention and mobility in Washington state. Final report, University of Washington. Retrieved from https://education.uw.edu/ sites/default/files/profiles/faculty/elfers/UW_Teacher_Report_Jan2017.pdf. 
Goddard, R., \& Goddard, M. (2006). Beginning teacher burnout in Queensland schools: Associations with serious intentions to leave. The Australian Educational Researcher, 33(2), 61-75. https://doi. org/10.1007/BF03216834.

Goldring, R., Taie, S., \& Riddles, M. (2014). Teacher attrition and mobility: Results from the 2012-13 teacher follow-up survey. First look. NCES 2014-077. National Center for Education Statistics. Retrieved 23 February 2018 from https://nces.ed.gov/pubsearch.

Griffeth, R. W., Hom, P., \& Gaertner, S. (2000). A meta-analysis of antecedents and correlations of employee turnover: Update, moderator tests, and research implications for the next millennium. Journal of Management, 26(3), 463-488. https://doi.org/10.1177/014920630002600305.

Guarino, C., Santibañez, L., \& Daley, G. (2006). Teacher recruitment and retention: A review of the recent empirical literature. Review of Educational Research, 76(2), 173-208. https://doi. org/10.3102/00346543076002173.

Guin, K. (2004). Chronic teacher turnover in urban elementary schools. Educational Evaluation and Policy Analysis, 12(42), 1-25.

Hargreaves, L., Cunningham, M., Hansen, A., McIntyre, D., Oliver, C., \& Pell, T. (2007). The status of teachers and the teaching profession in England: Views from inside and outside the profession. The Chancellor, Masters and Scholars of the University of Cambridge. Retrieved 14 December 2018 from https://webarchive.nationalarchives.gov.uk/20130323010453/https://www.education.gov.uk/ publications/eOrderingDownload/RR831A.pdf.

Heikonen, L., Pietarinen, J., Pyhältö, K., Toom, A., \& Soini, T. (2016). Early career teachers' sense of professional agency in the classroom: Associations with turnover intentions and perceived inadequacy in teacher-student interaction. Asia-Pacific Journal of Teacher Education, 45(3), 250-266. https://doi.org/10.1080/1359866X.2016.1169505.

Hong, J. Y. (2010). Pre-service and beginning teachers' professional identity and its relation to dropping out of the profession. Teaching and Teacher Education, 26(8), 1530-1543. https://doi.org/10.1016/j. tate.2010.06.003.

Hughes, G. (2012). Teacher retention: Teacher characteristics, school characteristics, organizational characteristics, and teacher efficacy. The Journal of Educational Research, 105(4), 245-255. https://doi. org/10.1080/00220671.2011.584922.

Husu, J., \& Toom, A. (2016). Opettajat ja opettajankoulutus-suuntia tulevaan. Selvitys ajankohtaisesta opettaja- ja opettajankoulutustutkimuksesta opettajankoulutuksen kehittämisohjelman laatimisen tueksi. [Teachers and teacher education-Directions for the future. Report of the current teacher and teacher education research to support their further development; in Finnish]. Ministry of Education and Culture. Publications 33. https://urn.fi/URN:ISBN:978-952-263-425-2.

Ingersoll, R. (2001). Teacher turnover and teacher shortages: An organizational analysis. American Educational Research Journal, 38(3), 499-534.

Ingersoll, R. (2002). The teacher shortage: A case of wrong diagnosis and wrong prescription. Association of secondary school principals. NASSP Bulletin. https://doi.org/10.1177/019263650208663103.

Ingersoll, R., \& Kralik, J. (2004). The impact of mentoring on teacher retention: What the research says. Philadelphia: University of Pennsylvania, Graduate School of Education, GSE Publications.

Ingersoll, R., \& Merill, L. (2012). Seven trends: The transformation of the teaching force. Philadelphia: Consortium for Policy Research in Education, University of Pennsylvania. https://www.cpre.org/ sites/default/files/workingpapers/1506_7trendsapril2014.pdf.

Ingersoll, R., \& Smith, T. (2003). The wrong solution to the teacher shortage. Educational Leadership, $60(8), 30-33$.

Johnson, S., Berg, J., \& Donaldson, M. (2005). Who stays in teaching and why: A review of the literature on teacher retention. Cambridge, MA: Harvard Graduate School of Education. https://assets.aarp. org/www.aarp.org_/articles/NRTA/Harvard_report.pdf.

Jokinen, H., Taajamo, M., \& Välijärvi, J. (2014). Pedagogical expertise in transition: Challenges of tomorrow. University of Jyväskylä, Finnish Institute for Educational Research. https://jyx.jyu.fi/bitst ream/handle/123456789/44968/978-951-39-6021-6.pdf?sequence=1.

Kari, J. (2002). Opettajan ammatin suosio ja opettajaksi hakeutumisen ongelmat. In Räihä, P., \& Kari, J. (Eds.), Opettajaksi soveltuvuuden moni-ilmeisyys. Opiskelijavalinta valtakunnallisesti puntaroituna. University of Jyväskylä. Publications in Education 74.

Kumpulainen, T. (Eds). (2017). Teachers and principals in Finland 2016. National Board of Education. Publications 2. Retrieved 23 March 2018 from https://www.oph.fi/download/185376_opettajat_ja_ rehtorit_Suomessa_2016.pdf. 
Ladd, H. (2011). Teachers' perceptions of their working conditions: How predictive of planned and actual teacher movement? Educational Evaluation and Policy Analysis, 33(2), 235-261.

Lau, P. S. Y., Yuen, M. T., \& Chan, R. M. C. (2005). Do demographic characteristics make a difference to burnout among Hong Kong secondary school teachers? Social Indicators Research, 71, 491-516. https://doi.org/10.1007/1-4020-3602-7_17.

Leung, D., \& Lee, W. (2006). Predicting intention to quit among Chinese teachers: Differential predictability of the components of burnout. Anxiety, Stress \& Coping, 19(2), 129-141. https://doi. org/10.1080/10615800600565476.

Lindén, J. (2010). An occupational calling transformed to basic labour? The changing nature and logic of teacher's work. Tampere University Press. https://urn.fi/urn:isbn:978-951-44-8001-0.

Lindqvist, P., Nordänger, U., \& Carlsson, R. (2014). Teacher attrition the first five years-A multifaceted image. Teaching and Teacher Education, 40, 94-103. https://doi.org/10.1016/j.tate.2014.02.005.

Little, J., \& Bartlett, L. (2002). Career and the commitment in the context of comprehensive school reform. Teachers and Teaching: Theory and Practice. https://doi.org/10.1080/135406002100000 486.

Locke, E. (1968). Toward a theory of task motivation and incentives. Organizational Behavior and Human Performance, 3, 157-189.

Luekens, M., Lyter, D., Fox, E., \& Chandler, K. (2004). Teacher attrition and mobility. Results from the teacher follow-up survey, 2000-01. U.S. Department of Education.

Lundström, U. (2015). Teacher autonomy in the era of New Public Management. Nordic Journal of Studies in Educational Policy. https://doi.org/10.3402/nstep.v1.28144.

MacDonald, D. (1999). Teacher attrition: A review of literature. Teaching and Teacher Education, 15, 839-848.

Maslach, C., Jackson, S. E., \& Leiter, M. P. (1996). Maslach burnout inventory manual. Mountain View, CA: CPP.

Ministry of Education and Culture. (2007). Teacher training 2020 (p. 44). Publications 2007. https://julka isut.valtioneuvosto.fi/bitstream/handle/10024/79634/tr44.pdf?sequence $=1$.

Mäkelä, K., \& Whipp, P. (2015). Career intentions of Australian physical education teachers. European Physical Education Review, 21(4), 504-520. https://doi.org/10.1177/1356336X15584088.

National Board of Education. (2010). Teachers in Finland [The healthy organization barometer]. Retrieved 3 April 2018 from https://www.oph.fi/julkaisut/2011/opettajat_suomessa_2010.

National Board of Education. (2017). Teachers and Principals in Finland. Reports 2017:2. Retrieved 23 March 2018 from: http://www.oph.fi/download/185376_opettajat_ja_rehtorit_Suomessa_2016.pdf.

Nissinen, K., \& Välijärvi, J. (2011). Forecasts for teacher demand and teacher training needs in Finland. University of Jyväskylä. Finnish Institute for Educational Research. Occasional Papers 43. https:// jyx.jyu.fi/bitstream/handle/123456789/37587/978-951-39-4622-7.pdf?sequence=1.

OAJ, The Trade Union of Education in Finland. (2018). Working life barometer 2017. Publications 5. Retrieved 15 February 2019 from https://www.oaj.fi/cs/oaj/Opetusalan\%20tyoolobarometri\%20201 7.

OECD. (2012). Education at a glance 2012: OECD indicators. Paris, France. Retrieved 23 March 2019 from https://www.oecd.org/education/school/34990905.pdf.

OECD. (2015). Teaching and learning international survey TALIS 2013. Examining teachers and principals in primary and secondary education. Finnish Institute for Educational Research. Publications 4. https://urn.fi/URN:ISBN:978-952-263-332-3.

OECD. (2019a). PISA 2018 results (volume I): What students know and can do. Paris: PISA, OECD Publishing. https://doi.org/10.1787/5f07c754-en.

OECD. (2019ba). TALIS 2018 results (volume I): Teachers and school leaders as lifelong learners. Paris: TALIS, OECD Publishing. https://doi.org/10.1787/1d0bc92a-en.

OECD Report. (2003). Attracting, developing and retaining effective teachers. Country Background Report in Finland. Retrieved 2 November 2018 from https://www.oecd.org/education/school/53287 20.pdf.

Parker, G. (2015). Teachers' autonomy. Research in Education, 93(1), 19-33. https://doi.org/10.7227/ RIE.0008.

Passy, R., \& Golden, S. (2010). Teacher resignation and recruitment survey. Slough: NFER. Retrieved 1 March 2019 from https://www.nfer.ac.uk/publications/LGK01/LGK01.pdf.

Pogodzinski, B., Youngs, P., \& Frank, K. (2013). Collegial climate and novice teachers' intent to remain teaching. American Journal of Education, 120(1), 27-54. https://doi.org/10.1086/673123. 
Pollari, P., Salo, O.-P., \& Koski, K. (2018). In teachers we trust-The finnish way to teach and learn. Inquiry in Education, 10(1), 4.

Pomaki, G., DeLongis, A., Frey, D., Short, K., \& Woehrle, T. (2010). When the going gets tough: Direct, buffering and indirect effects of social support on turnover intention. Teaching and Teacher Education, 26(6), 1340-1346. https://doi.org/10.1016/j.tate.2010.03.007.

Pyhältö, K., Pietarinen, J., \& Soini, T. (2015). When teaching gets tough-Professional community inhibitors of teacher-targeted bullying and turnover intentions. Improving Schools, 18(3), 1-14. https:// doi.org/10.1177/1365480215589663.

Pyhältö, K., Soini, T., \& Pietarinen, J. (2011). A systematic perspective on school reform: Principals' and chief education officers' perspectives on school development. Journal of Educational Administration, 49(1), 46-61. https://doi.org/10.1108/09578231111102054.

Ronfeldt, M., Loeb, S., \& Wyckoff, J. (2013). How teacher turnover harms student achievement. American Educational Research Journal, 50(1), 4-36. https://doi.org/10.3102/0002831212 463813.

Saeed, I., Waseem, M., Sikander, S., \& Rizwan, M. (2014). The relationship of turnover intention with job satisfaction, job performance, leader member exchange, emotional intelligence and organizational commitment. International Journal of Learning and Development, 4(2), 242-256. https://doi.org/10.5296/ijld.v4i2.6100.

Schaefer, L., Long, J. S., \& Clandinin, D. J. (2012). Questioning the research on early career teacher attrition and retention. Alberta Journal of Educational Research, 58, 106-121.

Skaalvik, E., \& Skaalvik, S. (2011). Teacher job satisfaction and motivation to leave the teaching profession: Relations with school context, feeling of belonging, and emotional exhaustion. Teaching and Teacher Education, 27(6), 1029-1038. https://doi.org/10.1016/j.tate.2011.04.001.

Smethem, L. (2007). Retention and intention in teaching careers: Will the new generation stay? Teachers and Teaching: Theory and Practise, 13(5), 465-480. https://doi.org/10.1080/13540600701561661.

Smithers, A., \& Robinson, P. (2003). Factors affecting teachers' decisions to leave the profession. Research Report 430. London: Department for Education and Skills.https://dera.ioe. ac.uk/4759/1/RR430.pdf.

Soini, T., Pyhältö, K., \& Pietarinen, J. (2010). Pedagogical well-being: Reflecting learning and wellbeing in teachers' work. Teachers and Teaching: Theory and Practice, 16(6), 735-751. https:// doi.org/10.1080/13540602.2010.517690.

Somech, A., \& Bogler, R. (2002). Antecedents and consequences of teacher organizational and professional commitment. Educational Administration Quarterly, 38(4), 555-577. https://doi. org/10.1177/001316102237672.

Southern, R. K. (2018). Teacher autonomy and centralization: Predicting school effectiveness. Doctoral dissertation, The University of Alabama.

Sutcher, L., Darling-Hammond, L., \& Carver-Thomas, D. (2016). A coming crisis in teaching? Teacher supply, demand, and shortages in the U.S. Palo Alto, CA: Learning Policy Institute. https://learningpolicyinstitute.org/product/coming-crisis-teaching.

Toom, A., \& Husu, J. (2016). Finnish teachers as makers of the many. Balancing between broad pedagogical freedom and responsibility. In H. Niemi \& A. Toom (Eds.), Miracle of education: The principles and practises of teaching and learning in Finnish schools. Rotterdam: Sense Publishers.

VAKAVA Statistics. (2017). Retrieved February 2018, from https://www.helsinki.fi/fi/verkostot/vakav a/vakava-koe/tilastoja.

Van Droogenbroeck, F., \& Spruyt, B. (2014). To stop or not to stop an empirical assessment of the determinants of early retirement among active and retired senior teachers. Research on Aging, 36(6), 753-777. https://doi.org/10.1177/0164027513519449.

Webb, R., Vulliamy, G., Hämäläinen, S., Sarja, A., Kimonen, E., \& Nevalainen, R. (2004). Pressures, rewards and teacher retention: A comparative study of primary teaching in England and Finland. Scandinavian Journal of Educational Research, 48(2), 169-188. https://doi.org/10.1080/00313 83042000198530 .

Zou, M. (2015). Gender, work orientations and job satisfaction. Work, Employment \& Society, 29(1), 3-22. https://doi.org/10.1177/0950017014559267.

Publisher's Note Springer Nature remains neutral with regard to jurisdictional claims in published maps and institutional affiliations. 
Katariina Räsänen is a Ph.D. student at the Doctoral Programme in Educational Studies, School of Applied Educational Science and Teacher Education, University of Eastern Finland. Her research interest is in teachers' work-related well-being and retention.

Janne Pietarinen, Ph.D. is a professor of teacher education at the School of Applied Educational Science and Teacher Education, University of Eastern Finland, and Adjunct Professor at the University of Tampere. His research interests are in educational transitions, pupil and teacher learning, and well-being in the context of sustainable school development. He is Co-PI in the Learning and Development in School research group together with Tiina Soini and Kirsi Pyhältö.

Kirsi Pyhältö, Ph.D. is at the faculty of Educational Sciences, University of Oulu, and Centre for University Teaching and Learning, Faculty of Educational Sciences, University of Helsinki, Finland. She is a research director at the Centre for University Teaching and Learning, University of Helsinki and professor of Educational Science at the University of Oulu. Her research interests include learning and the wellbeing and professional agency of in-service teachers. She is a Co-PI in the Learning and Development in School research group together with Tiina Soini and Janne Pietarinen.

Tiina Soini, Ph.D. is a research director at the Faculty of Education and Culture, Tampere University and Adjunct Professor at the University of Eastern Finland. Her research interests are in the learning and wellbeing of educational communities, with a special focus on teacher communities in comprehensive school. She is a Co-PI in the Learning and Development in School research group together with Kirsi Pyhältö and Janne Pietarinen.

Pertti Väisänen, Ph.D. is a professor of Educational Sciences and Research on Learning and Teaching at the School of Applied Educational Science and Teacher Education, University of Eastern Finland. His research interests include learning and studying in higher education, student motivation, learning strategies and performance, teacher education, teaching practice and pre-service teachers' professional development. 